\title{
Photoluminescence and X-Ray Diffraction Properties of Europium and Silver Co-Doped Tantalum-Oxide Thin Films Deposited by Co-Sputtering
}

\author{
Keisuke Shimada, Kenta Miura, Ryosuke Fujii, Masahiro Kanakubo, Wataru Kada, \\ Osamu Hanaizumi
}

Graduate School of Science and Technology, Gunma University, Kiryu, Japan

Email:mkenta@gunma-u.ac.jp

How to cite this paper: Shimada, K., Miura, K., Fujii, R., Kanakubo, M., Kada, W. and Hanaizumi, O. (2017) Photoluminescence and X-Ray Diffraction Properties of Europium and Silver Co-Doped TantalumOxide Thin Films Deposited by Co-Sputtering. Journal of Materials Science and Chemical Engineering, 5, 35-40. https://doi.org/10.4236/msce.2017.52004

Received: January 12, 2017

Accepted: February 13, 2017

Published: February 16, 2017

Copyright $\odot 2017$ by authors and Scientific Research Publishing Inc. This work is licensed under the Creative Commons Attribution-NonCommercial International License (CC BY-NC 4.0). http://creativecommons.org/licenses/by-nc/4.0/

(c) () () Open Access

\begin{abstract}
We fabricated europium and silver co-doped tantalum-oxide $\left(\mathrm{Ta}_{2} \mathrm{O}_{5}: \mathrm{Eu}, \mathrm{Ag}\right)$ thin films using a simple co-sputtering method for the first time, and we evaluated their photoluminescence (PL) and X-ray diffraction (XRD) properties. We found that the most remarkable PL peak at a wavelength of $615 \mathrm{~nm}$ due to $\mathrm{Eu}^{3+}$ can be enhanced by $\mathrm{Ag}$ doping, and the strongest PL peak can be obtained from a $\mathrm{Ta}_{2} \mathrm{O}_{5}: \mathrm{Eu}, \mathrm{Ag}$ thin film after annealing at $1000^{\circ} \mathrm{C}$. Based on XRD measurements, we found that $\mathrm{Ag}_{2} \mathrm{Ta}_{8} \mathrm{O}_{21}$ crystalline phases produced by $\mathrm{Ag}$ doping are very important and $\mathrm{Eu}_{3} \mathrm{TaO}_{7}$ phases should be avoided in order to enhance the objective PL peak from our $\mathrm{Ta}_{2} \mathrm{O}_{5}: \mathrm{Eu}, \mathrm{Ag}$ thin films.
\end{abstract}

\section{Keywords}

Tantalum Oxide, Europium, Silver, Co-Sputtering, Photoluminescence

\section{Introduction}

Tantalum pentoxide $\left(\mathrm{Ta}_{2} \mathrm{O}_{5}\right)$ is a high-refractive-index, stable material widely used in passive optical elements such as $\mathrm{Ta}_{2} \mathrm{O}_{5} / \mathrm{SiO}_{2}$ multilayered wavelength filters for dense wavelength-division multiplexing (DWDM). It has also been used as a high-index material of $\mathrm{Ta}_{2} \mathrm{O}_{5} / \mathrm{SiO}_{2}$ multilayered photonic-crystal elements for the visible to near-infrared range fabricated using radio-frequency (RF) bias sputtering [1] [2]. Additionally, it can be used as an anti-reflection coating material for silicon solar cells [3].

Many studies on rare-earth-doped $\mathrm{Ta}_{2} \mathrm{O}_{5}$ have been conducted because $\mathrm{Ta}_{2} \mathrm{O}_{5}$ is a promising host material for new phosphors due to its lower phonon energy 
than other popular oxide materials such as $\mathrm{SiO}_{2}$ [4]. Thus far, we have fabricated various rare-earth doped $\mathrm{Ta}_{2} \mathrm{O}_{5}$ thin films using a simple co-sputtering method and obtained various photoluminescence (PL) properties from the films [5] [6] [7] [8] [9]. We reported on red or orange PL from europium (Eu)-doped $\mathrm{Ta}_{2} \mathrm{O}_{5}$ $\left(\mathrm{Ta}_{2} \mathrm{O}_{5}: \mathrm{Eu}\right)$ thin films deposited using the same co-sputtering method [6]. Four PL peaks at wavelengths of $600,620,650$, and $700 \mathrm{~nm}$ were observed from the films after annealing, and the $620-\mathrm{nm}$ peak was the strongest among the four peaks. The peaks seemed to be the results of the ${ }^{5} \mathrm{D}_{0} \rightarrow{ }^{7} \mathrm{~F}_{1},{ }^{5} \mathrm{D}_{0} \rightarrow{ }^{7} \mathrm{~F}_{2},{ }^{5} \mathrm{D}_{0} \rightarrow{ }^{7} \mathrm{~F}_{3}$, and ${ }^{5} \mathrm{D}_{0} \rightarrow{ }^{7} \mathrm{~F}_{4}$ transitions of $\mathrm{Eu}^{3+}$, respectively [6]. In our recent study, we fabricated $\mathrm{Eu}$ and cerium $(\mathrm{Ce})$ co-doped $\mathrm{Ta}_{2} \mathrm{O}_{5}\left(\mathrm{Ta}_{2} \mathrm{O}_{5}: \mathrm{Eu}, \mathrm{Ce}\right)$ thin films and evaluated their PL properties [9]. Four remarkable PL peaks at wavelengths of 600 , 620,700 and $705 \mathrm{~nm}$ were observed from the film annealed at $900^{\circ} \mathrm{C}$. The intensities of the 700- and 705-nm peaks due to the ${ }^{5} \mathrm{D}_{0} \rightarrow{ }^{7} \mathrm{~F}_{4}$ transition of $\mathrm{Eu}^{3+}$ were much stronger than those of the $600-\mathrm{nm}\left({ }^{5} \mathrm{D}_{0} \rightarrow{ }^{7} \mathrm{~F}_{1}\right)$ and $620-\mathrm{nm}\left({ }^{5} \mathrm{D}_{0} \rightarrow{ }^{7} \mathrm{~F}_{2}\right)$ peaks because of energy transfer from $\mathrm{Ce}^{3+}$ to $\mathrm{Eu}^{3+}$ in the film [9].

Recently, Dousti et al. reported that luminescence from erbium (Er)-doped tellurite glasses can be enhanced by silver ( $\mathrm{Ag})$ co-doping [10]. In this short report, we will present the first fabrication of Eu and $\mathrm{Ag}$ co-doped $\mathrm{Ta}_{2} \mathrm{O}_{5}\left(\mathrm{Ta}_{2} \mathrm{O}_{5}\right.$ : $\mathrm{Eu}, \mathrm{Ag}$ ) thin films using our co-sputtering method and the first observation of the enhanced PL from the films. We will also discuss the relationship between their PL properties and crystallizability.

\section{Experiments}

\subsection{Preparation}

$\mathrm{Ta}_{2} \mathrm{O}_{5}$ :Eu, Ag thin films were deposited using a RF magnetron sputtering system (ULVAC, SH-350-SE). A $\mathrm{Ta}_{2} \mathrm{O}_{5}$ disc (Furuuchi Chemical Corporation, 99.99\% purity, diameter $100 \mathrm{~mm}$ ) was used as a sputtering target in the system. We placed two $\mathrm{Eu}_{2} \mathrm{O}_{3}$ pellets (Furuuchi Chemical Corporation, 99.9\% purity, diameter $20 \mathrm{~mm}$ ) and five Ag quarter pellets (Furuuchi Chemical Corporation, 99.99\% purity, diameter $20 \mathrm{~mm}$ ) on the erosion area of the $\mathrm{Ta}_{2} \mathrm{O}_{5}$ disc (Figure 1). We prepared the Ag quarter pellets by cutting Ag pellets using a diamond-wire saw.

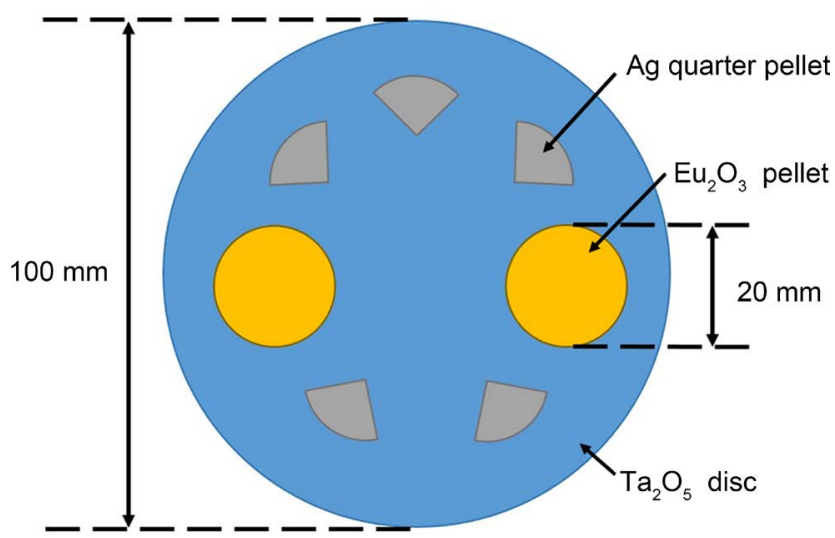

Figure 1. Schematic diagram of the sputtering target for co-sputtering $\mathrm{Eu}_{2} \mathrm{O}_{3}, \mathrm{Ag}$, and $\mathrm{Ta}_{2} \mathrm{O}_{5}$. 
The flow rate of argon gas introduced into the vacuum chamber was $15 \mathrm{sccm}$, and the RF power supplied to the target was set at $200 \mathrm{~W}$. Commercial fused-silica plates (thickness $1 \mathrm{~mm}$ ) were used as substrates, and they were not heated during deposition. After deposition, we annealed the $\mathrm{Ta}_{2} \mathrm{O}_{5}: \mathrm{Eu}, \mathrm{Ag}$ thin films in ambient air at $700^{\circ} \mathrm{C}, 800^{\circ} \mathrm{C}, 900^{\circ} \mathrm{C}$, or $1000^{\circ} \mathrm{C}$ for $20 \mathrm{~min}$ using an electric furnace (Denken, KDF S-70). We set the annealing time to $20 \mathrm{~min}$, the standard condition for our rare-earth-doped $\mathrm{Ta}_{2} \mathrm{O}_{5}$ thin films [5] [6] [7] [8] [9].

\subsection{Evaluation}

The PL spectra of the annealed films were measured using a dual-grating monochromator (Roper Scientific, SpectraPro 2150i) and a CCD detector (Roper Scientific, Pixis: $100 \mathrm{~B}$, electrically cooled to $-75^{\circ} \mathrm{C}$ ). A He-Cd laser (Kimmon, IK3251R-F, wavelength $\lambda=325 \mathrm{~nm}$ ) was used to excite the films. The X-ray diffraction (XRD) patterns of the films were recorded using an X-ray diffractometer (RIGAKU, RINT2200VF+/PC system).

\section{Results and Discussion}

Figure 2 plots PL spectra of the $\mathrm{Ta}_{2} \mathrm{O}_{5}: \mathrm{Eu}, \mathrm{Ag}$ thin films annealed at $700^{\circ} \mathrm{C}$, $800^{\circ} \mathrm{C}, 900^{\circ} \mathrm{C}$, and $1000^{\circ} \mathrm{C}$. The most remarkable and strongest PL peak at $\lambda=$ $615 \mathrm{~nm}$ due to the ${ }^{5} \mathrm{D}_{0} \rightarrow{ }^{7} \mathrm{~F}_{2}$ transition of $\mathrm{Eu}^{3+}$ [6] [9] was observed from the film annealed at $1000^{\circ} \mathrm{C}$. Figure 3 plots XRD patterns of the films annealed at $700^{\circ} \mathrm{C}, 800^{\circ} \mathrm{C}, 900^{\circ} \mathrm{C}$, and $1000^{\circ} \mathrm{C}$. Many diffraction peaks due to hexagonal $\mathrm{Ta}_{2} \mathrm{O}_{5}\left(\delta-\mathrm{Ta}_{2} \mathrm{O}_{5}\right)$ and $\mathrm{Ag}_{2} \mathrm{Ta}_{8} \mathrm{O}_{21}$ crystalline phases were observed from the film annealed at $1000^{\circ} \mathrm{C}$. Therefore, these phases in our $\mathrm{Ta}_{2} \mathrm{O}_{5}: \mathrm{Eu}, \mathrm{Ag}$ thin films seem to be important for obtaining strong PL peaks due to $\mathrm{Eu}^{3+}$ from the films.

Figure 4 plots PL spectra of $\mathrm{Ta}_{2} \mathrm{O}_{5}: \mathrm{Eu}, \mathrm{Ag}$ and $\mathrm{Ta}_{2} \mathrm{O}_{5}: \mathrm{Eu}$ (without $\mathrm{Ag}$ co-doping) thin films annealed at $1000^{\circ} \mathrm{C}$. We found that the objective $615-\mathrm{nm}$ peak due to $\mathrm{Eu}^{3+}$ was enhanced by $\mathrm{Ag}$ doping. The peak intensity from the $\mathrm{Ta}_{2} \mathrm{O}_{5}: \mathrm{Eu}, \mathrm{Ag}$ film was 1.7 times stronger than that of the $\mathrm{Ta}_{2} \mathrm{O}_{5}: \mathrm{Eu}$ film. Figure 5 presents the XRD pattern of the $\mathrm{Ta}_{2} \mathrm{O}_{5}: \mathrm{Eu}$ thin film annealed at $1000^{\circ} \mathrm{C}$. Diffraction peaks due to $\delta-\mathrm{Ta}_{2} \mathrm{O}_{5}$ and $\mathrm{Eu}_{3} \mathrm{TaO}_{7}$ crystalline phases were observed from the film. In contrast, as indicated in Figure 3(b), no $\mathrm{Eu}_{3} \mathrm{TaO}_{7}$ phases were observed from the $\mathrm{Ta}_{2} \mathrm{O}_{5}: \mathrm{Eu}, \mathrm{Ag}$ thin film, although the annealing temperature of the film was the same as that of the $\mathrm{Ta}_{2} \mathrm{O}_{5}: \mathrm{Eu}$ thin film. Therefore, it seems that the above-mentioned $\mathrm{Ag}_{2} \mathrm{Ta}_{8} \mathrm{O}_{21}$ crystalline phases produced by $\mathrm{Ag}$ doping should exist and the $\mathrm{Eu}_{3} \mathrm{TaO}_{7}$ phases should be avoided in order to enhance the objective PL peak from the film. We will continue to investigate the mechanism of enhancement by Ag doping.

\section{Conclusion}

We reported the first fabrication of $\mathrm{Ta}_{2} \mathrm{O}_{5}: \mathrm{Eu}, \mathrm{Ag}$ thin films using our simple co-sputtering method. We found that the most remarkable PL peak at $\lambda=615$ $\mathrm{nm}$ due to $\mathrm{Eu}^{3+}$ can be enhanced by $\mathrm{Ag}$ doping, and the strongest PL peak can be obtained from a $\mathrm{Ta}_{2} \mathrm{O}_{5}: \mathrm{Eu}, \mathrm{Ag}$ thin film after annealing at $1000^{\circ} \mathrm{C}$. Based on 


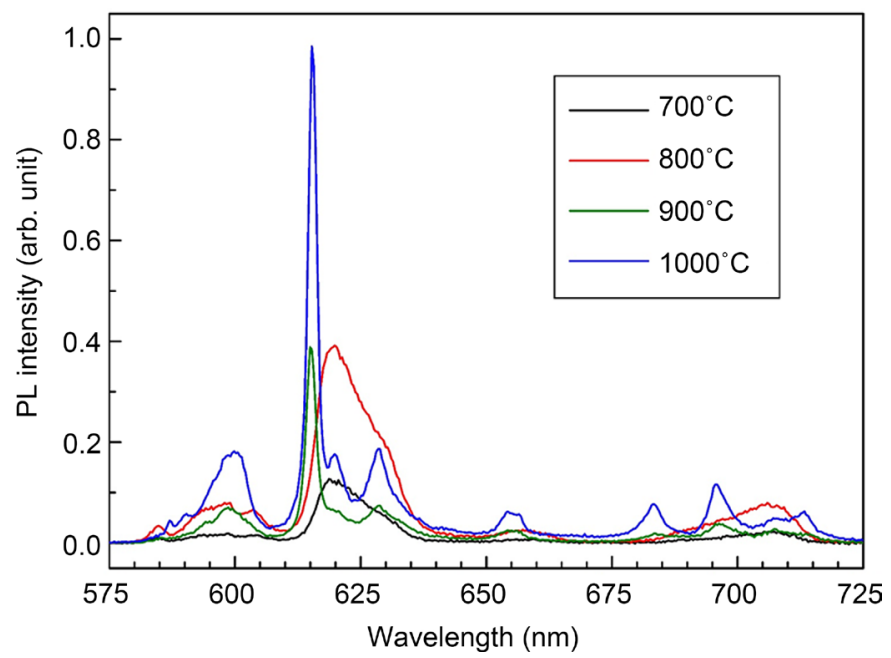

Figure 2. PL spectra of $\mathrm{Ta}_{2} \mathrm{O}_{5}: \mathrm{Eu}, \mathrm{Ag}$ thin films annealed at $700^{\circ} \mathrm{C}, 800^{\circ} \mathrm{C}, 900^{\circ} \mathrm{C}$, and $1000^{\circ} \mathrm{C}$.

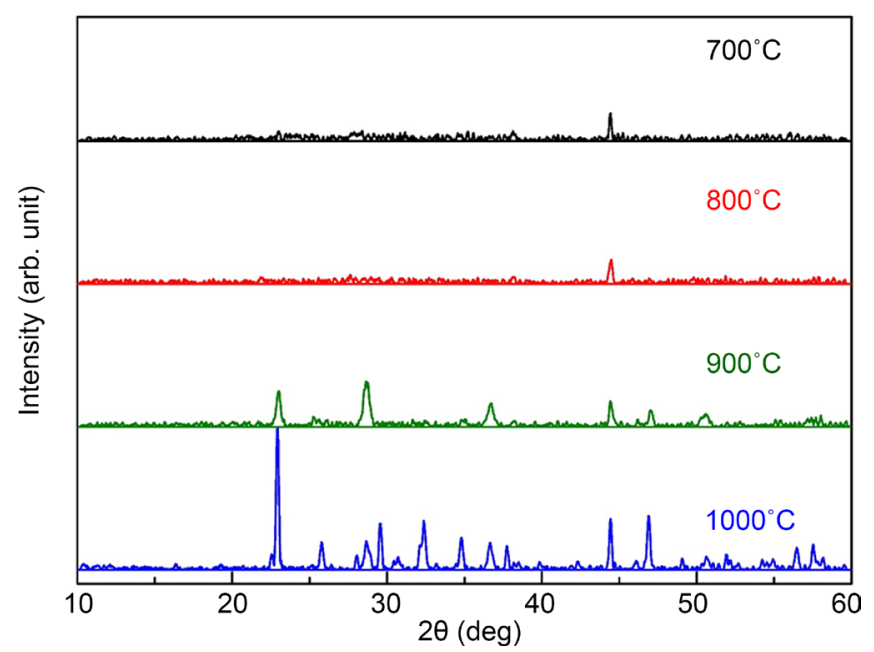

(a)

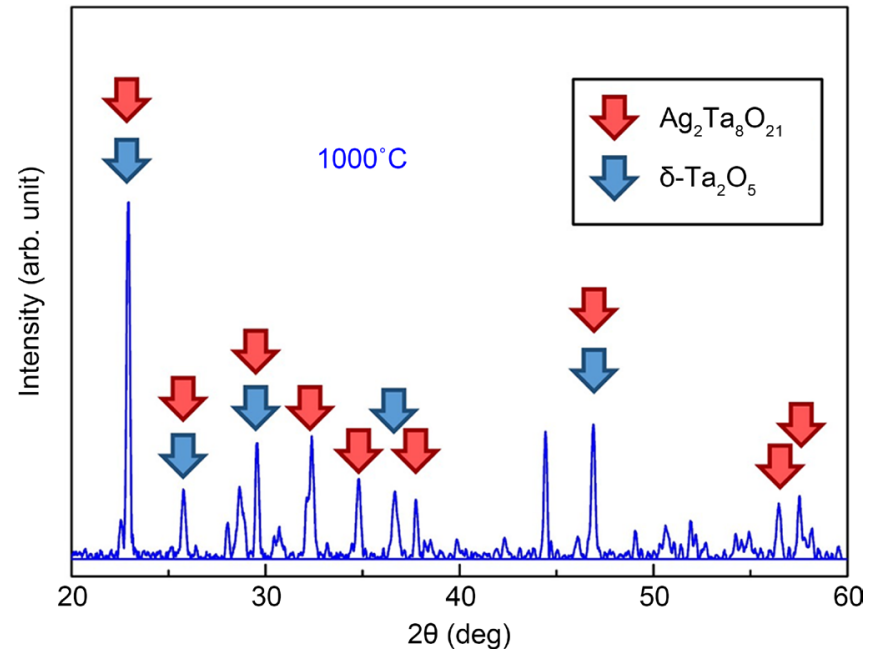

(b)

Figure 3. (a) XRD patterns of $\mathrm{Ta}_{2} \mathrm{O}_{5}: \mathrm{Eu}, \mathrm{Ag}$ thin films annealed at $700^{\circ} \mathrm{C}, 800^{\circ} \mathrm{C}, 900^{\circ} \mathrm{C}$, and $1000^{\circ} \mathrm{C}$. (b) Analysis results of the XRD pattern of the film annealed at $1000^{\circ} \mathrm{C}$. 


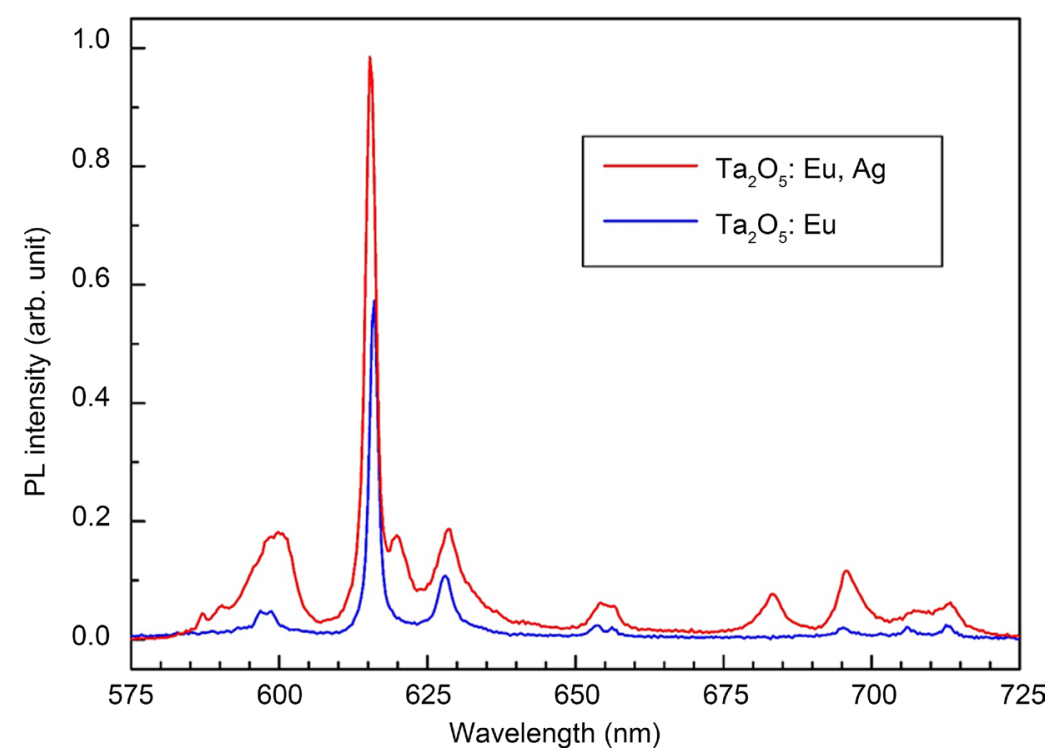

Figure 4. PL spectra of $\mathrm{Ta}_{2} \mathrm{O}_{5}: \mathrm{Eu}, \mathrm{Ag}$ and $\mathrm{Ta}_{2} \mathrm{O}_{5}: \mathrm{Eu}$ thin films annealed at $1000^{\circ} \mathrm{C}$.

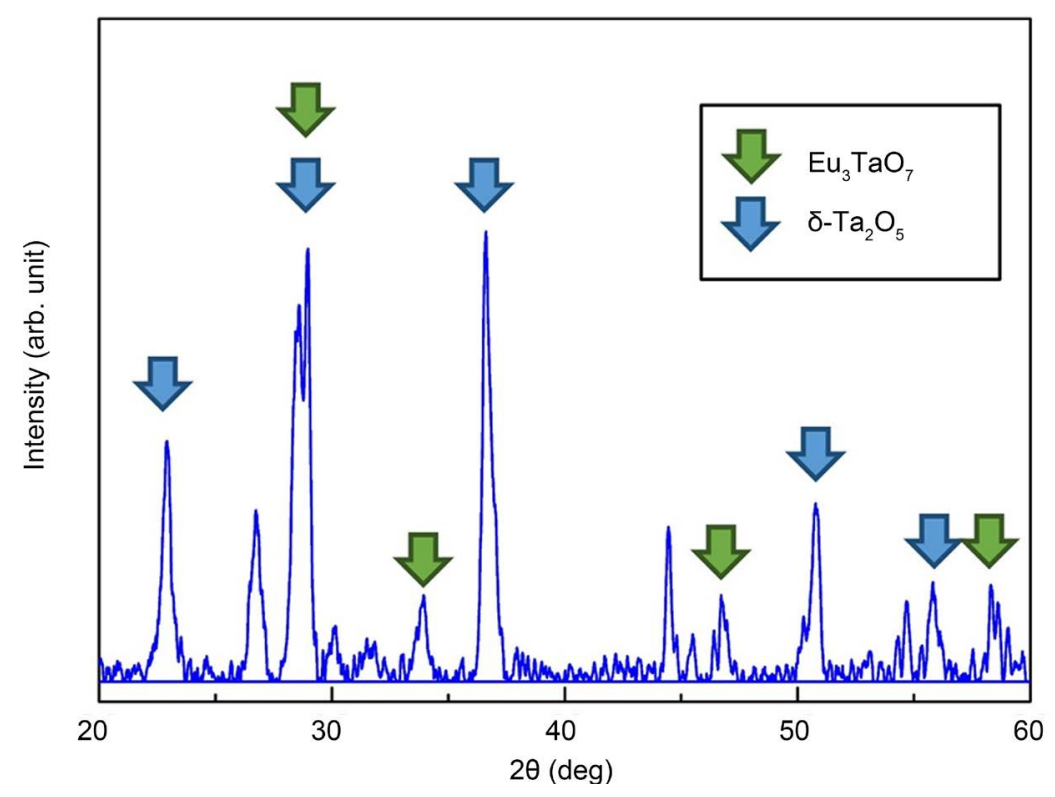

Figure 5. XRD pattern of a $\mathrm{Ta}_{2} \mathrm{O}_{5}:$ Eu thin film annealed at $1000^{\circ} \mathrm{C}$.

XRD measurements, we found that $\mathrm{Ag}_{2} \mathrm{Ta}_{8} \mathrm{O}_{21}$ crystalline phases produced by $\mathrm{Ag}$ doping are very important and that $\mathrm{Eu}_{3} \mathrm{TaO}_{7}$ phases should be avoided in order to enhance the objective PL peak of our $\mathrm{Ta}_{2} \mathrm{O}_{5}: \mathrm{Eu}, \mathrm{Ag}$ thin films.

\section{Acknowledgements}

Part of this work was supported by JSPS KAKENHI Grant Number 26390073. Part of this work was conducted at the Organization to Promote Research and University-Industry Collaboration, Gunma University, Japan.

\section{References}

[1] Hanaizumi, O., Miura, K., Saito, M., Sato, T., Kawakami, S., Kuramochi, E. and 
Oku, S. (2000) Frontiers Related with Automatic Shaping of Photonic Crystals. IEICE Transactions on Electronics, E83-C, 912-919.

[2] Sato, T., Miura, K., Ishino, N., Ohtera, Y., Tamamura, T. and Kawakami, S. (2002) Photonic Crystals for the Visible Range Fabricated by Autocloning Technique and Their Application. Optical and Quantum Electronics, 34, 63-70. https://doi.org/10.1023/A:1013382711983

[3] Cid, M., Stem, N., Brunetti, C., Beloto, A.F. and Ramos, C.A.S. (1998) Improvements in Anti-Reflection Coatings for High-Efficiency Silicon Solar Cells. Surface and Coatings Technology, 106, 117-120. https://doi.org/10.1016/S0257-8972(98)00499-X

[4] Sanada, T., Wakai, Y., Nakashita, H., Matsumoto, T., Yogi, C., Ikeda, S., Wada, N. and Kojima, K. (2010) Preparation of $\mathrm{Eu}^{3+}$-Doped $\mathrm{Ta}_{2} \mathrm{O}_{5}$ Phosphor Particles by Sol-Gel Method. Optical Materials, 33, 164-169.

https://doi.org/10.1016/j.optmat.2010.08.018

[5] Singh, M.K., Fusegi, G., Kano, K., Bange, J.P., Miura, K. and Hanaizumi, O. (2009) Intense Photoluminescence from Erbium-Doped Tantalum Oxide Thin Films Deposited by Sputtering. IEICE Electronics Express, 6, 1676-1682.

https://doi.org/10.1587/elex.6.1676

[6] Miura, K., Arai, Y., Osawa, T. and Hanaizumi, O. (2012) Light-Emission Properties of Europium-Doped Tantalum-Oxide Thin Films Deposited by Radio-Frequency Magnetron Sputtering. Journal of Light \& Visual Environment, 36, 64-67. https://doi.org/10.2150/jlve.36.64

[7] Miura, K., Osawa, T., Yokota, Y., Suzuki, T. and Hanaizumi, O. (2014) Fabrication of Tm-Doped $\mathrm{Ta}_{2} \mathrm{O}_{5}$ Thin Films Using a Co-Sputtering Method. Results in Physics, 4, 148-149. https://doi.org/10.1016/j.rinp.2014.08.011

[8] Miura, K., Osawa, T., Yokota, Y. and Hanaizumi, O. (2014) Fabrication and Evaluation of $\mathrm{Ta}_{2} \mathrm{O}_{5}: \mathrm{Y}_{2} \mathrm{O}_{3}$ Co-Sputtered Thin Films. Results in Physics, 4, 185-186. https://doi.org/10.1016/j.rinp.2014.09.004

[9] Miura, K., Suzuki, T. and Hanaizumi, O. (2015) Photoluminescence Properties of Europium and Cerium Co-Doped Tantalum-Oxide Thin Films Prepared Using Co-Sputtering Method. Journal of Materials Science and Chemical Engineering, 3, 30-34. https://doi.org/10.4236/msce.2015.38005

[10] Dousti, M.R., Sahar, M.R., Ghoshal, S.K., Amjad, R.J. and Arifin, R. (2013) Plasmonic Enhanced Luminescence in $\mathrm{Er}^{3+}: \mathrm{Ag}$ Co-Doped Tellurite Glass. Journal of Molecular Structure, 1033, 79-83. https://doi.org/10.1016/j.molstruc.2012.08.022 
Submit or recommend next manuscript to SCIRP and we will provide best service for you:

Accepting pre-submission inquiries through Email, Facebook, LinkedIn, Twitter, etc. A wide selection of journals (inclusive of 9 subjects, more than 200 journals)

Providing 24-hour high-quality service

User-friendly online submission system

Fair and swift peer-review system

Efficient typesetting and proofreading procedure

Display of the result of downloads and visits, as well as the number of cited articles Maximum dissemination of your research work

Submit your manuscript at: http://papersubmission.scirp.org/

Or contact msce@scirp.org 